\title{
KOMPETENCIJE MEDICINSKE SESTRE U KONZULTATIVNOJ PSIHIJATRIJI
}

\author{
Ivana Blažinović, Andrea Gurović, Dalibor Karlović \\ Klinika za psihijatriju, KBC Sestre milosrdnice, Referentni centar za konzultativnu psihijatriju Ministarstva \\ zdravlja Republike Hrvatske, Zagreb, Hrvatska
}

Rad je primljen: 18.3.2015.

Rad je revidiran: 2.4.2015.

Rad je prihvaćen: 29.4.2015.

\section{SAŽETAK}

Do 35 posto bolesnika koji se liječe na somatskim odjelima ima uz somatsku bolest i neki oblik psihijatrijskih bolesti ili poremećaja koji su najčešće neprepoznati. Suvremeni trend je uz liječenje somatske bolesti obuhvatiti psihičku i socijalnu komponentu u liječenju i njezi bolesnika to jest holistički ili biopsihosocijalni pristup bolesniku. Iz tog razloga u suvremenoj psihijatriji se razvila i posebna grana medicine-konzultativna psihijatrija.

U tom smislu psihijatrijske medicinske sestre počinju naglašavati holistički pristup somatskom bolesniku kroz svakodnevni rad. Sestre koje rade na takvom odjelu konzultativno suradne psihijatrije moraju biti adekvatno educirane, kako o psihijatrijskim bolestima, tako i o tjelesnim oboljenjima, te etiologiji njihove međusobne povezanosti koja će pridonijeti što kvalitetnijem pružanju sestrinske skrbi za bolesnika. Sestre u konzultativno suradnoj psihijatriji također moraju imati određeno iskustvo i adekvatno obrazovanje u radu na psihijatrijskom odjelu uz dodatnu edukaciju kroz razna predavanja i seminare kako bi adekvatno mogle prepoznati etiologiju emocionalnog odgovora na tjelesnu bolest. Cilj ovog rada je prikazati kompetencije i važnost medicinske sestre u konzultativnom psihijatrijskom radu.

Ključne riječi: kompetencije, medicinska sestra, konzultativna psihijatrija

Osoba za razmjenu informacija:

Prof. dr. sc. Dalibor Karlović,

e-mail: dalibor.karlovic@gmail.com

\section{UVOD}

Život svakog čovjeka u suvremenom svijetu prepun je čimbenika koji izazivaju frustraciju. Stres kojemu smo neminovno izloženi potiče sve veći broj psihosomatskih oboljenja koja su evidentno u porastu.Zbog navedenih oboljenja sve su veće potrebe i za psihijatrijskim intervencijama, pa s time u vezi postoji porast potreba za konzultativnom psihijatrijom.Ovaj se trend uočava i u našoj sredini, oko 30 \% hospitaliziranih bolesnika u bolnici ima psihičke poremećaje, a u oko $10 \%$ svih hospitaliziranih bolesnika prvo mjesto zauzima liječenje delirija. Konzultativna psihijatrija proučava psihičke odnosno emocionalne odgovore pojedinca na adaptaciju, implikaciju i posljedice somatske bolesti. Interdisciplinarni način liječenja omogućuje da psihijatar i njegov psihijatrijski tim bude uključen u liječenje primarno tjelesnih bolesti. Takav način liječenja dovodi do bržeg uspostavljanja remisije bolesti, te potvrđuje da se duša i tijelo ipak ne mogu promatrati odvojeno.

Osnova rada konzultativne psihijatrije je izgradnja veza između psihijatrije i somatske medicine $s$ ciljem stvaranja biopsihosocijalnog pristupa u liječenju. Konzultativna psihijatrija uključuje klinički rad, edukaciju i istraživanje na polju stvaranja veza između psihijatrije i somatske medicine.Pa se kao takva može promatrati kao primjena psihosomatskog pristupa, ali i kao konstitutivni i integralni dio psihosomatske medicine. Osniva se na potvrđivanju bazične premise da psihološko i tjelesno nisu 
odvojeni entiteti koji se bore jedan protiv drugoga već su dva integralna aspekta svake osobe kao psihobiološkog organizma. Iz ovoga slijedi potreba prijenosa holističkog shvaćanja u praktično povezivanje somatske medicine i psihijatrije.

Konzultativna psihijatrija proizašla je iz svijesti da svaki medicinski postupak mora uključivati poznavanje i razumijevanje psiholoških aspekata bolesti, terapijskih postupaka, sredstava, pomagala koji se koriste u liječenju bolesnika i sredine u kojoj bolesnik boravi tijekom i nakon liječenja. Normativno gledajući, liječnici bi morali voditi računa o tome čega je sve proizvod bolesno ponašanje osim neposrednog i posrednog utjecaja povrede, metaboličkih, toksičkih, degenerativnih i drugih činitelja. Konzultativni psihijatri trebali bi kao članovi tima što potpunije osvijetliti psihološki kontekst svakog bolesnika i njegovog poremećaja, i na taj način pomoći bolesniku da se lakše nosi sa svojom bolesti, a ostalim članovima tima pomoći da u bolesniku vide ljudsko biće u njegovom krajnje složenom biopsihosocijalnom jedinstvu.

Krucijalna funkcija konzultacijskog psihijatra je da procjeni stupanj stresa koji pacijenti stvaraju kod osoba koje im pružaju zdravstvenu njegu i kod svojih obitelji, kapacitet bolničkog osoblja i članova obitelji da se adaptiraju na pacijente i njihove bolesti i iznad svega, sposobnost osoblja i obitelji da provedu ili barem da potpomognu psihijatrijsku skrb.

Kolika je važna implementacija konzultativno suradnog psihijatrijskog modela u bolnicama općeg tipa govori i to da oko $5 \%$ svih bolnički liječenih bolesnika na tjelesnim odjelima su imali psihijatrijsku konzultaciju, zatim oko $30 \%$ bolesnika u bolnicama općeg tipa ima neki psihijatrijski poremećaj. Od tih 30\% bolesnika, 10\% ima akutni psihoorganski sindrom, a oko $10 \%$ poremećaj raspoloženja, $5 \%$ poremećaj prilagodbe.

Liaison je izvorno francuska riječ iako se koristi i u engleskom jeziku, a označava vezu, povezanost, suradnju. Pojmom liaison psihijatrija označava se povezivanje psihijatrije i somatske medicine, što je proizašlo iz potrebe jačanja međusobnih veza između ovih dvaju pristupa.Konzultativna psihijatrija može se definirati kao subspecijalizacija psihijatrije, kao klinički servis, ali i edukacija i istraživanje na ne psihijatrijskim medicinskim odjelima. Ova definicija zahtjeva pojašnjenje, pogotovo termin klinički servis jer on obuhvaća suradnju psihijatra u dijagnostici, terapiji i prevenciji mogućih psiholoških poteškoća organskog bolesnika. Ovaj vid rada zahtjeva i posebnu edukaciju psihijatara za rad na ne psihijatrijskim odjelima. Prvenstveno jer zahtjeva interdisciplinarni pristup, timski rad, a u tom kontekstu i promatranje grupne dinamike u okviru tima, bolje reći u promatranju i interveniranju na razini odnosa bolesnik-članovi tima.

Konzultativna psihosomatska medicina je grana medicine koja pokušava spojiti cjelokupnu medicinu, spektar svih medicinskih specijalnosti i sve bolesnike u sustav zdravstvene zaštite uključujući edukacijske i istraživačke funkcije.Temelji se na proučavanju i razumijevanju psihologije i fiziologije, odnosno psihe i tijela.

Konzultativnu psihijatriju se može definirati i kao subspecijalnost koja se bavi dijagnozom, liječenjem i proučavanjem kao i prevencijom psihičkih poremećaja kod fizički oboljelih pacijenata,kao i onih koji ispoljavaju somatske promjene to jest koji svoje emocionalno stanje iskazuju kroz somatske simptome zbog kojih traže medicinsku pomoć.

\section{OSNOVNI ZADACI KONZULTATIVNE PSIHIJATRIJE}

Osnovni zadatak konzultativne psihijatrije je poboljšanje opće kvalitete brige o bolesniku pri čemu se naročito vodi računa o psihološkim i socijalnim činiocima koji mogu utjecati, u vrijeme samog liječenja, na razvoj bolesti, ali isto tako i na utjecaj ovih činitelja na pojavu bolesti, njen tijek i na kraju na sam tijek medicinskog tretmana.

Konzultativni psihijatar u svom radu na somatskom odjelu promatra i ukazuje na važnost odnosa liječnik-bolesnik, na psihološki utjecaj raznih medicinskih i kirurških intervencija, terapijskih procedura kao i na posebnosti raznih terapijskih okruženja (intenzivne njege, sterilne jedinice i slično). $\mathrm{Na}$ temelju svoje kliničke, edukativne i istraživačke aktivnosti konzultativna psihijatrija igra ključnu ulogu 
u izgradnji i održavanju veza između psihološke i organske medicine.

Aktivnost konzultativne psihijatrije prvenstveno je usmjeravana na bolesnika, na njegova psihološka proživljavanja i reagiranje na bolest.

Važan zadatak konzultativne psihijatrije je njegovo direktno sudjelovanje u liječenju bolesnika koje se vrlo često javlja u stresnim situacijama kao što su priopćavanje ozbiljnih dijagnoza, sama reakcija na hospitalizaciju ili neku medicinsku intervenciju i slično, a najčešće ima oblik kriznog interveniranja ili kratke psihoterapije.

\section{POVIJEST KONZULTATIVNE PSIHIJATRIJE}

- Povijesno su psihijatrijski bolesnici bili odvojeni od ostalih somatskih bolesnika, time su psihijatriji bili odvojeni od ostalih kolega za somatsku medicinu

- Osnivaju psihijatrijski odjeli unutar općih bolnica da bi ojačali vezu između psihijatrije i organske medicine ali isto tako da bi poboljšali njegu bolesnika kao i edukaciju i klinička istraživanja

- Otvaranjem psihijatrijskih odjela u općim bolnicama, između dva svjetska rata, počinje i suradnja psihijatara sa drugim specijalistima

- Konzultativno suradna psihijatrija počinje se razvijati između dva svjetska rata prošlog stoljeća kad su psihijatrijski odjeli i psihijatri postali dio općih bolnica

- Liaison psihijatrija začeta je u SAD-u sredinom 30-tih godina prošlog stoljeća, pionirima suradne psihijatrije smatraju se Helen Flander Dunbar, Franz Alexander i Harold G. Wolff.

- Helen Dunbar je pokrenula istraživanje u ozračju opće bolnice o psihosocijalnim aspektima nekih organskih bolesti i na taj način zapravo bila prvi istraživač u području liaisonske psihijatrije. Ona je bila zagovaratelj holističkog - sveobuhvatnog pristupa u medicinskoj praksi, teoriji i istraživanju čime je približila Mayerovu psihobiologiju psihosomatskoj medicini.

- Pojam liaison psihijatrije prvi put koristi Edward G. Billings 1937. godine u članku u kojem je dao naglasak na smanjenje troškova odjela gdje je bila ustrojena suradna psihijatrija.

- Prvi organizirani konzultativno suradni odjel u SAD-u 1933. godine

- Konceptualni razvoj 1945-1970. označava napor nekolicine pojedinaca posebice Zbignjeva Lipowskog da se definira pojam konzultativne psihijatrije

- Razvoj liaison psihijatrije u Hrvatskoj nije imao tako brz razvoj, kao što je to bilo u razvijenim zemljama

- Danas je konzultativna psihijatrija toliko uznapredovala da čini posebnu granu psihijatrije

\section{ORGANIZACIJA RADA KONZULTATIVNO SURADNE PSIHIJATRIJA U KBC "SESTRE MILOSRDNICE“}

- 1897. godine je u Bolnici milosrdnih sestara i napisan prvi znanstveno-stručni rad na našem području iz tematike kojom se danas i bave konzultativno suradni psihijatri a vezan je uz psihotične kliničke slike koje su posljedica traume glave. Rad je napisao i jedan od osnivača Medicinskog fakulteta u Zagrebu prof.dr. Miroslav Čačković (Čačković M. Slučaj traumatske psihoze izliječene trepanacijom. Liječnički vjesnik 1897; 19: 360.)

- 1939 godine u Hrvatskoj, u Bolnici "Sestara milosrdnica" otvara se psihijatrijski odjel, prvi takav u nas i šire

- Dr.Josip Glaser-prvi hrvatski stručno znanstveni članak o suradnji psihijatara i ostalih specijalista i psihičkim smetnjama u tjelesnih bolesnika 1946.

- Naglašava važnost psihijatrijskih odjela u općim bolnicama

- Desetljećima je konzultativno-suradni model realiziran u sklopu polikliničko-konzilijarne službe Klinike za psihijatriju kroz konzilijarne preglede

- Od 2002. godine na Klinici za psihijatriju i službeno djeluje Odjel za konzultativno-suradnu psihijatriju i psihosomatsku medicinu koji se bavi prevencijom, dijagnostikom i terapijom u po- 
dručju konzultativno suradne psihijatrije i psihosomatske medicine.

- Navedeni Odjel je jedini i prvi takav odjel koji je i formalno organiziran i uspostavljen u nekoj bolnici u Republici Hrvatskoj

Konzultativno suradna psihijatrija i psihosomatska medicina u KB" Sestre milosrdnice“ je prvi takav formalno osnovan odjel u Republici Hrvatskoj, a koji je preuzet kao modificirani talijanski model. Konzultativno suradna psihijatrija aktivno se provodi na gotovo svim kliničkim odjelima KB“Sestre milosrdnice":

1. odjelima intenzivne skrbi (interna i kirurška intenzivna jedinica, koronarna jedinica, interventna gastroenterologija, opća interna)

2. odjelima onkologije i hematologije gdje je od izuzetne važnosti psihoonkološko savjetovalište za bolesnike i obitelj

3. odjelu ginekologije (gdje je nužna pomoć ovisnicama nakon poroda, ženama sa postpartalnim poremećajima, te psihijatrijskim bolesnicama koje čuvaju trudnoću)

4. na kirurgiji ( posebno kod operacija želuca kod pretilih osoba)

5. ORL-u i kirurgiji lica, glave i vrata (korektivni zahvati i plastične operacije)

6. na neurokirurgiji gdje je važno praćenje bolesnika nakon operacije hipofize, hipotalamusa i frontalnog režnja

7. na dermatologiji kod poremećaja sheme vlastitog tijela, dizmorfofobije, pruriga, psorijaze, pemfigusa, akni i alopecije

8. urologija, posebno kod dijaliza

9. u gastroenterologiji (kod ovisnika o alkoholu)

10.u endokrinologiji, posebno kod dijabetičara kada je psihijatrijska konzultacija nužna kako bi se bolesnicima pomoglo da se što lakše nose sa svojom bolesti

11. na neurologiji zbog učestalih depresija i akutnog psihoorganskog sindroma nastalog kao posljedice moždanog udara

12. $\mathrm{u}$ anesteziologiji u centru za liječenje boli.
Osoblje Konzultativno-suradne psihijatrije i psihosomatske medicine čine: pročelnik, glavna sestra, liječnici-psihijatri (ukupno 18), a koji su svi zaposleni na Klinici, zatim specijalizanti psihijatrije, psiho$\log$, te socijalni radnik.

Uloga Pročelnika Kliničke jedinice za konzultativno suradnu psihijatriju i psihosomatsku medicinu:

- Koordinira rad, izrađuje plan rada i sudjeluje u svakodnevnom radu Odjela

- Brine za stručnost rada i surađuje s Predstojnicima, Pročelnicima i Voditeljima Klinika, Zavoda i Odjela i unutar bolnice dogovara potrebnu suradnju za pružanje konzultativno suradne djelatnosti

- Surađuje s Predstojnikom Klinike, liječnicima specijalistima, te specijalizantima unutar Kliničke jedinice konzultativno suradne psihijatrije

- Provodi znanstveni rad i osmišljava nove mogućnosti unutar Kliničke jedinice

- Osigurava informatizaciju Odjela i registra za dobivanje vrijednih podataka o psihijatrijskim konzultacijama

- S glavnom sestrom kliničke jedinice nadzire poslove u krugu djelovanja Konzultativno suradne psihijatrije.

Uloga glavne sestre Kliničke jedinice konzultativno suradne psihijatrije:

- Vodi medicinsku dokumentaciju

- Vodi raspored rada unutar Kliničke jedinice u dogovoru s glavnom sestrom Klinike i glavnim sestrama unutar Klinike

- Koordinira s ostalim glavnim sestrama na ostalim Klinikama, Zavodima i Odjelima gdje se provode dijagnostički i terapijski zahvati

- Koordinira s liječnicima Klinike koji trebaju obavljati dijagnostičke i terapijske postupke na Klinikama, Zavodima, Odjelima i Poliklinikama bolnice

- Vrši unos podataka u informatički sustav koji čini okosnicu registra Kliničke jedinice iz kojeg se dobivaju vrijedni podaci o bolničkim potrebama za psihijatrijskim konzultacijama (formira se baza podataka konzultativno suradnih usluga) 
- Educira medicinske sestre na odjelima tjelesne medicine o procesu njege psihijatrijskog bolesnika dok je na liječenju na odjelu somatske medicine

- Pruža pomoć u postavljanju psihijatrijskih sestrinskih dijagnoza kod somatskih bolesnika i educira somatske bolesnike o načinu kako se emocionalno nositi s bolešću.

\section{FUNKCIJE KONZULTATIVNE PSIHIJATRIJE}

- Bolesnici se moraju adekvatno zbrinuti uz holistički pristup

- Postići što bolje cjelokupno zdravstveno stanje bolesnika uz zadovoljavanje svih njegovih potreba kako bi rezultat bio zadovoljan i adekvatno zbrinut bolesnik.

- Godišnje se u KB"Sestre milosrdnice" provede oko 1200 psihijatrijskih konzultacija, pri čemu se dnevno prosječno obavi oko 5 konzultacija što se odnosi na oko 3\% bolnički liječenih pacijenata.

\begin{tabular}{cc}
\hline Godina psihijatrijske konzultacije & Broj psihijatrijskih konzultacija \\
\hline 1999. & 697 \\
2000. & 706 \\
2001. & 748 \\
2002. & 751 \\
2003. & 767 \\
2004. & 784 \\
2005. & 701 \\
2006. & 816 \\
2007. & 1078 \\
2008. & 1064 \\
2009. & 1200 \\
\hline
\end{tabular}

“istraživanje provedeno u sklopu odjela konzultativno suradne psihijatrije i psihosomatske medicine

\section{EDUKACIJSKA FUNKCIJA}

- Provesti edukaciju tjelesnih specijalista o psihičkoj bolesti i bolesnicima, a takav oblik edukacije već provode psihijatri po dolasku na „tjelesni"odjel
- Prilikom pružanja psihijatrijske konzultacije, trebaju biti prisutni i liječnici koji su ordinirali konzultaciju, te kroz razgovor vidjeti koji je bio razlog poziva i što zapravo nadležni specijalist očekuje od psihijatra i kakvo je njegovo shvaćanje trenutnog stanja bolesnika

- Nakon provedenog strukturiranog razgovora $s$ bolesnikom nadležnom liječniku psihijatar će opisati trenutno psihičko stanje bolesnika i tražiti povratnu informaciju od „tjelesnog“ liječnika.

- Potrebna je edukacija medicinskih sestara koje rade na „tjelesnim, odjelima o primjerenoj $\mathrm{i}$ adekvatnoj, te psihijatrijskom pacijentu prilagođenoj njezi i zdravstvenoj skrbi

\section{ISTRAŽIVAČKA FUNKCIJA}

Konzultativno suradna psihijatrija provodi i razna znanstvena istraživanja koja su prilagođena i organizirana po načelu primjenjivosti u svakodnevnom stručnom radu. To zapravo znači da svi podaci dobiveni iz registra i baze podataka stvorene kroz sustav informatizacije svakodnevnog rada predstavljaju osnovu iz koje se dobivaju realni podaci o praktičnom funkcioniranju Konzultativne psihijatrije.

\section{ADMINISTRATIVNA FUNKCIJA}

Svaka Klinika KB "Sestre milosrdnice" na svojim odjelima ima specijalne uputnice za psihijatrijsku konzultaciju pisane u duplikatu (original ostaje na Klinici koja je tražila psihijatrijsku konzultaciju, a kopija ostaje na Odjelu konzultativno suradne psihijatrije).

Uputnica se sastoji od četiri dijela, a to su:

1. prvi dio-opći podaci

2. drugi dio-podaci o bolesniku

3. treći dio- psihijatrijski podaci o bolesniku i razlozi za psihijatrijsku konzultaciju prema mišljenju specijaliste somatske medicine

4. četvrti dio-dio koji ispunjava osoblje konzultativno suradne psihijatrije 


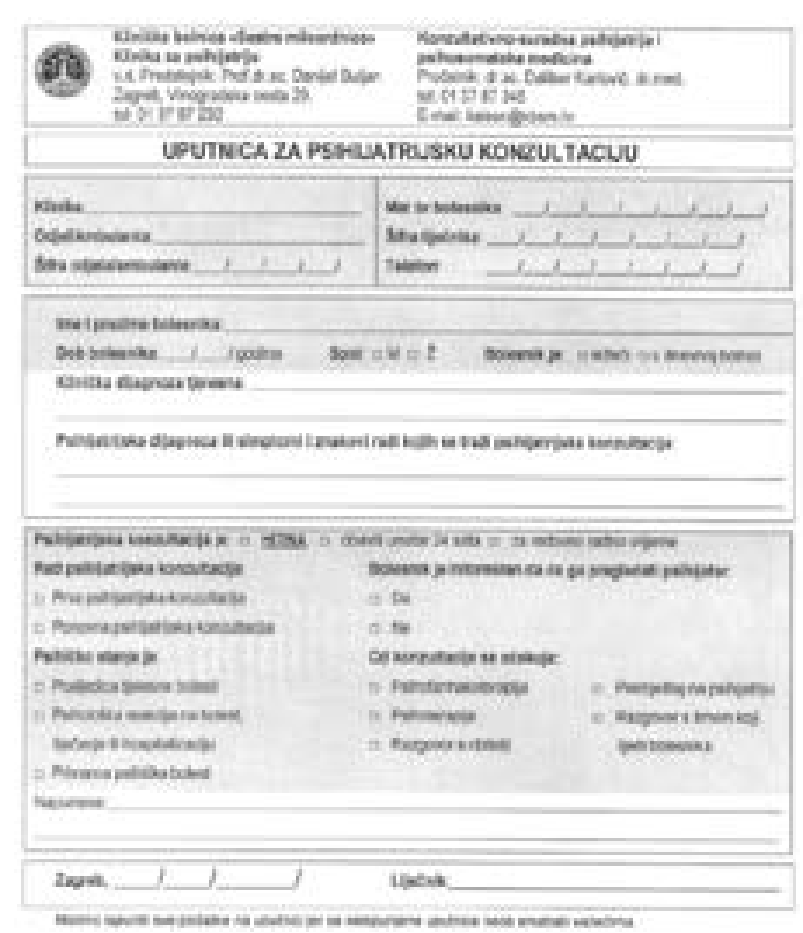

Čitav proces psihijatrijskih konzultacija je informatiziran tako da Odjel uključuje registar i bazu podataka konzultativno suradnih usluga u KB“Sestre milosrdnice“. Upravo je ta baza podataka temelj za provedbu raznih epidemioloških istraživanja i praćenja potreba pojedinih Klinika za psihijatrijskim pregledima.

\section{PSIHIJATRIJSKA KONZULTACIJA}

Psihijatar se najčešće uključuje u organsku medicinu zbog:

1. psihijatrijskih aspekata organske bolesti

2. psihijatrijskih komplikacija organske bolesti

3. psihičkih reakcija na organsku bolest

4. psihičkih posljedica stresa

5. somatskih reprezentacija psihičke bolesti

6. psihosomatskih bolesti

Najčešći psihijatrijski poremećaji koji zahtijevaju psihijatrijsku konzultaciju na somatskim odjelima: suicidalno ponašanje, depresija, agitacija, halucinacije, poremećaji spavanja, somatizacija, dezorijentacija, nesuradljivost u liječenju, sposobnost samostalnog odlučivanja o operativnom zahvatu ili nekoj za život nužnoj pretrazi

Djelatnost Konzultativno suradne psihijatrije:

- Hitna psihijatrijska konzultacija koja mora biti pružena unutar 15 minuta, a što će biti i posebno naznačeno na uputnici za psihijatrijsku konzultaciju

- Konzultacija koja se mora provesti unutar 24 sata, konzultacija koja će biti provedena u redovno radno vrijeme pojedinog psihijatra

- Postoji i mogućnost provedbe psihijatrijske vizite na „tjelesnim odjelima“ ukoliko se za tu vrstu konzultacije ukaže potreba, a tada bi se već pregledani bolesnik od strane psihijatra još u nekoliko navrata obilazio kako bi se moglo kontinuirano pratiti poboljšanje ili eventualno pogoršanje psihičkog statusa

Interdisciplinarni tim konzultativno suradne psihijatrije:

1. Psihijatar koji inače ima „svoj“ odjel u kojem radi u dijelu radnog vremena odnosno u svoje redovno radno vrijeme

2. Dežurni psihijatar koji je zapravo i "starija služba" u dežurstvu

3. Glavna sestra koja vodi administraciju, registar i bazu podataka, te surađuje sa sestrama koje rade na „tjelesnim“ odjelima

4. Psiholog koji provodi psihoterapiju bolesnika i vrši psihotestiranja na temelju kojih se može utvrditi stupanj i vrsta psihičkog poremećaja, struktura osobnosti pacijenta, te obrambeni mehanizmi i sposobnost suočavanja i nošenja sa problemima

5. Socijalni radnik koji će rješavati neka eventualna bolesnikova socijalna pitanja i probleme, kontaktirati bolesnikovu obitelj, razgovarati zajednički o nastalim problemima, te načinu njihovog što uspješnijeg rješavanja i postizanja što bolje zajedničke kvalitete života 


\section{Interdisciplinarni tim u konzultativnoj psihijatriji}

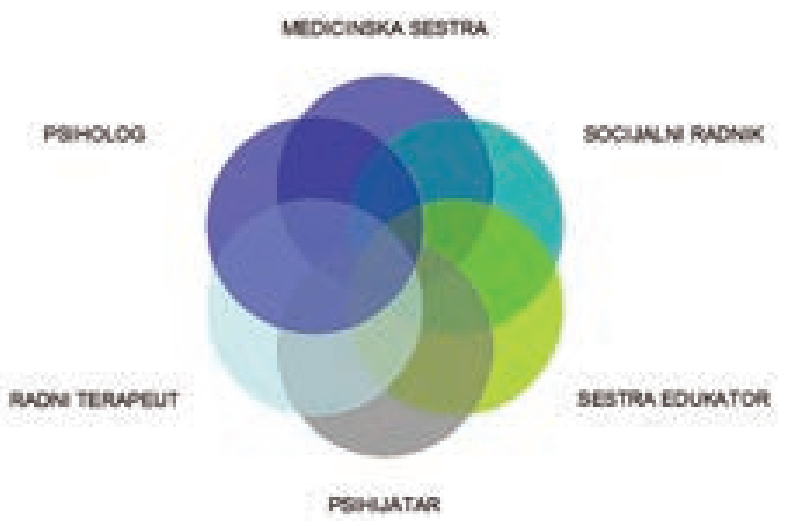

\section{KOMPETENCIJE MEDICINSKE SESTRE U KONZULTATIVNOJ PSIHIJATRIJI, PCLN (psychiatric consultation-liaison nurse):}

- Internacionalni naziv za sestru koja radu na Odjelu konzultativno-suradne psihijatrije

- Konzultativno-suradna psihijatrija u sestrinstvu prisutna je u većini zemalja u svijetu,posebno u SAD-u, Australiji, Novom Zelandu, Velikoj Britaniji, većini europskih zemalja, a tek od nedavno prisutna je i u Hrvatskoj i to u Kliničkoj bolnici "Sestre milosrdnice"

- Rad sestara u konzultativno-suradnoj psihijatriji zapravo je prisutan već više od 40 godina

- 1987.godine manja grupa PCLN-a okupila se na svojoj prvoj konferenciji u SAD-u, te su osnovale posebnu interesnu grupu uz potporu ANA-e (American nurses association) i objavile standarde za praktičan rad sestara u konzultativno-suradnoj psihijatriji, te principe rada 1990.godine.

- ista grupa sestara oformila je međunarodno društvo PCLN 1996.godine, te udruženje PCLN za edukaciju i istraživanje 1999.godine.

PCLN je napredna i u praksi primjenjiva subspecijalnost psihijatrijskih sestara. Medicinska sestra u konzultativnoj psihijatriji je vrlo značajan dio multidisciplinarnog tima. Važna je funkcija sestre kao liasona između pacijenta, psihijatra i članova obitelji jer one potvrđuju i podržavaju relacije između pacijenta i njegove interakcije sa ostalom okolinom.
Uspješnost sestrinske uloge u konzultativnoj psihijatriji uključuje razumijevanje ljudskog ponašanja, poznavanje psihijatrijskih i sestrinskih principa, permanentnost i sposobnost prilagodbe na različite funkcije i pažljivu upotrebu komunikacijskih vještina kao i otvorenost za pacijentove osjećaje i stavove.

PCLN su dužne provoditi različite zadatke iz područja zdravstvene njege bolesnika,utvrditi kompetencije sestre u konzultativno suradnoj psihijatriji, definirati sestrinsku dijagnozu, odnosno problem iz područja zdravstvene njege, utvrditi potrebe bolesnika, planirati intervencije iz područja sestrinstva konzultativno suradne psihijatrije, evaluirati i procijeniti uspješnost provedenih postupaka.

Sestre koje rade na takvom odjelu konzultativno suradne psihijatrije moraju biti adekvatno educirane, kako o psihijatrijskim bolestima, tako i o tjelesnim oboljenjima, te etiologiji njihove međusobne povezanosti koja će pridonijeti što kvalitetnijem pružanju sestrinske skrbi za bolesnika.

Znanje i vještine PCLN su usmjerene na procjenu rizika za nastanak psihičkih poremećaja,pregled mentalnog statusa,znanje iz psihofarmakologije,na psihološke posljedice somatske bolesti.Važna je uloga je PCLN u sestrinskoj konzultaciji na drugim ne psihijatrijskim odjelima gdje integrirajući holistički pristup pacijentima sa psihičkim tegobama pomaže u uklanjanju problema. Sestrinske konzultacija uključuje direktan rad sa pacijentom i njegovom obitelji.

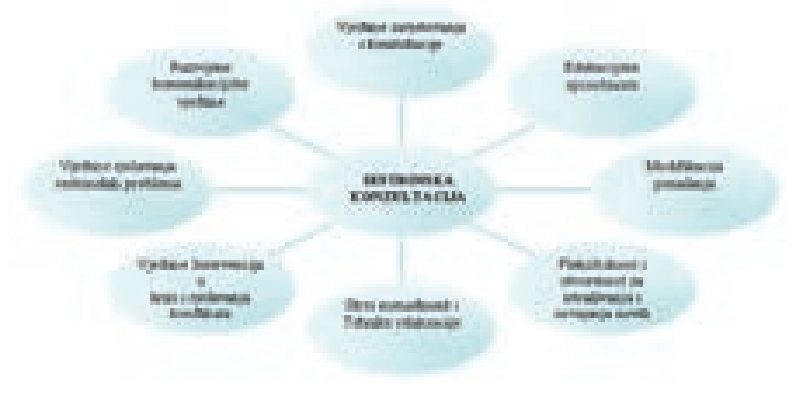




\section{KOMPETENCIJE PSIHIJATRIJSKE KONZULTATIVNO SURADNE SESTRE}

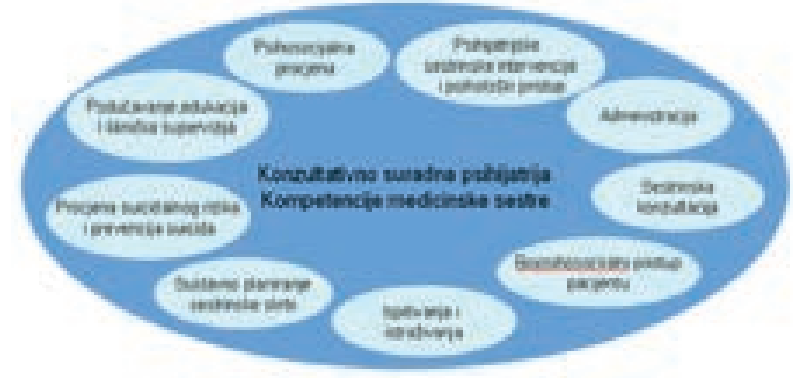

KOMPETENCIJE MEDICINSKE SESTRE U KONZULTATIVNOJ PSIHIJATRIJI

1. Psihijatrijske sestrinske intervencije,

2. Specijalističke intervencije u psihijatrijskoj njezi,

3. Psihološke sestrinske intervencije i psihosocijalna procjena,

4. Sustavno planiranje sestrinske skrbi,

5. Sestrinska konzultacija,

6. Istraživački rad u sestrinstvu,

7. Edukacija i klinička supervizija,

8. Administracija.

\section{PSIHIJATRIJSKE SESTRINSKE KOMPETENCIJE}

1. Suradnja sa drugim članovima multidisciplinarnog tima, u svrhu razvoja i primjene raznih specifičnih znanja s obzirom na posebnosti pacijentovih mentalno zdravstvenih potreba,

2. Provođenje profesionalnog, terapijskog, prema pacijentu orijentiranog odnosa uz promoviranje cilja prema željenim promjenama,

3. Holistički pristupa pacijentu i pokazuje osjetljivost u rješavanju psihijatrijskih poremećaja kod somatskih pacijenata,

4. Procjenjuje, ocjenjuje i prilagođava dinamiku terapijskog odnosa i intervencije psihijatrijske njege somatskom bolesniku u odnosu na znanstvene preporuke,

5. Zastupa pacijentove terapijske potrebe ako on to nije u mogućnosti,

6. Medicinska sestra mora steći određeno iskustvo i adekvatno psihijatrijsko obrazovanje uz dodatnu edukaciju kroz razna predavanja i seminare kako bi adekvatno mogle prepoznati etiologiju emocionalnog odgovora na tjelesnu bolest,

7. Koristi intervencije za promicanje terapijskog odnosa i stjecanje odnosa povjerenja,

8. Promatra, analizira i diskutira s pacijentom učinke okruženja u odnosu na njega,

9. Koristi terapijski odnos za promicanje pozitivnih kliničkih rezultata i postignuća,

10. Posjeduje sposobnost uspostave kvalitete međuljudskih odnosa i sposobnost brzog uključivanja i prilagodbe u sustav rada samog odjela,

11. Medicinska sestra u konzultativnoj psihijatriji mora imati razvijene emocionalne kompetencije (samosvijest, samopouzdanje, empatija, socijalne vještine),

12. Koordinira s ostalim glavnim sestrama na ostalim Klinikama i Odjelima gdje se provode dijagnostički i terapijski zahvati,

13. Koordinira s liječnicima Klinike koji pružaju psihijatrijsku konzultaciju,

14. Sestre koje rade na „tjelesnim“ odjelima pobliže upoznati sa načinom zbrinjavanja i specifičnim potrebama psihijatrijskih bolesnika uz uklanjanje predrasuda o psihijatrijskim bolesnicima.

\section{SUSTAVNO PLANIRANJE SESTRINSKE SKRBI U KONZULTATIVNOJ PSIHIJATRIJI}

1. Prikuplja i analizira podatke,koji se odnose na fizičko,psihološko,kulturalno,duhovno i socijalno stajalište pacijentovog zdravlja,te formira individualizirani plan zdravstvene njege,

2. Dokumentira rezultate procjene sestrinskih psihijatrijskih intervencija,

3. Procjenjuje,ocjenjuje i ako je potrebno prilagođava intervencije psihijatrijske njege u odnosu na znanstveno stručne preporuke,

4. Evidentira aktivnosti i postupke psihijatrijske njege i evaluira učinkovitost zdravstvene njege,

5. Promatra i interpretira djelovanje somatskog liječenja,interpretira psihičke promjene kod pacijenta i ako je potrebno preporučuje promjene. 


\section{PSIHOLOŠKE SESTRINSKE INTERVENCIJE I PSIHOSOCIJALNA PROCJENA}

1. Fleksibilnost i osposobljenost za asistiranje, procjenjivanje, edukaciju, te kompletnu psihosocijalnu skrb bolesnika,

2. Prepoznavanje mogućih psiholoških reakcija na tjelesnu bolest uz stalno naglašavanje i promicanje biopsihosocijalnog pristupa bolesniku.

\section{ZNANSTVENO ISTRAŽIVAČKI RAD}

1. Sudjelovanje u provođenju znanstveno istraživačkog rada u sklopu odjela konzultativne psihijatrije,

2. Provođenje znanstvenih istraživanja koja su prilagođena i organizirana po načelu primjenjivosti u svakodnevnom stručnom radu,

3. Pratiti relevantna znanstvena istraživanja za poboljšanje kvalitete sestrinske skrbi.

\section{EDUKACIJSKE INTERVENCIJE}

Medicinska sestra u konzultativnoj psihijatriji:

1. razumije principe učenja i podučavanja, uključuje pacijenta i obitelj u proces edukacije,

2. educira somatske bolesnike o načinu kako se emocionalno nositi s bolešću,

3. procjenjuje učinkovitost edukacije zajedno sa pacijentom i prilagođava aktivnosti s ciljem poboljšanja stila života,

4. provodi edukaciju sestara na somatskim odjelima o načinu zbrinjavanja i specifičnim potrebama psihijatrijskog bolesnika kao i procesu psihijatrijske skrbi; ta edukacija uključuje:

- pružanje pomoći u postavljanju psihijatrijskih dijagnoza iz područja zdrastvene njege kod somatskih bolesnika

- educira somatske bolesnike o načinu kako se emocionalno nositi s bolešću

- edukacija o primjerenoj i adekvatnoj te psihihijatrijskom pacijentu prilagođenoj zdrastvenoj njezi

- medicinske sestre koje rade na "tjelesnim“ odjelima pobliže upoznati sa načinom zbrinjavanja i specifičnim potrebama psihijatrij- skih bolesnika uz uklanjanje predrasuda o psihijatrijskim bolesnicima

\section{ADMINISTRATIVNE AKTIVNOSTI SESTRE U KONZULTATIVNOJ PSIHIJATRIJI}

1. Vođenje medicinske dokumentacije i raspored rada unutar odjela Konzultativne

Psihijatrije,

2. Formiranje baze podataka konzultativno suradnih usluga,

3. Unošenje podataka u informatički sustav registra Odjela iz kojeg se dobivaju podaci o bolničkim potrebama za psihijatrijskim konzultacijama.

\section{ZAKLJUČAK}

Konzultativno-suradna psihijatrija i psihosomatska medicina u KB" Sestre milosrdnice" je prvi takav formalno osnovan odjel u Republici Hrvatskoj. Najvažniji zadatak Konzultativno suradne psihijatrije i psihosomatske medicine i somatske medicine je postići za pacijenta što bolje zdravstveno stanje uz individualni i holistički pristup učinkovito uključivanje pacijenta u taj proces.Svaka konzultativno suradna medicinska sestra mora biti u stanju razumjeti i prepoznati utjecaj tjelesne boli na emocionalno funkcioniranje bolesnika, te imati adekvatno obrazovanje i iskustvo u radu sa psihijatrijskim bolesnicima.Uspješnost sestrinske skrbi uključuje razumijevanje ljudskog ponašanja, poznavanje psihijatrijskih sestrinskih principa permanentnost i sposobnost prilagodbe na različite funkcije i zahtjeve sestrinske uloge u svrhu dobrobiti pacijenta kao i pažljivu upotrebu komunikacijskih vještina i otvorenost za pacijentove osjećaje i stavove.

Sestra u svom radu istražuje jedinstvene, prema pacijentu usmjerene terapijske odnose uz primjenu znanja psihijatrijske njege, tjelesnog zdravlja, psihosocijalnog blagostanja uz stalnu implementaciju holističkog pristupa pacijentu. Potrebno stalno usavršavanje i edukacija usmjerava nas kako najučinkovitije primijeniti svoje sestrinsko znanje u daljnjem radu i postizanju zamijećenih postignuća u području konzultativno suradne psihijatrije. 


\section{LITERATURA}

1. Gregurek, R. (2006): Suradna i konzultativna psihijatrija. Zagreb: Školska knjiga

2. Adamović, V. (2005): Psihosomatska medicina i konsultativna psihijatrija. Beograd: JP Službeni list SCG

3. American Nurses Association. (2005). Magnet recognition program: Recognizing excellence in nursing services. Silver Spring, MD: American Nurses Credentialing Center.

5. Cross, W. \& Moore, A. (2006). Psychiatric consultation liaison nurse (P.C.L.N.) project report. Clayton: Southern Health Nursing Education and Research.

6. Sharrock, J. \& Happell, B. (2002). The psychiatric consultation-liaison nurse: Thriving in a general hospital setting. International Journal of Mental Health Nursing, 11, 24-33.

7. Wand, T. \& Happell, B. (2001). The mental health nurse: Contributing to improved outcomes for patients in the emergency department. Accident and Emergency Nursing, 9, 166-176.

8. Roberts, D. (1998). Making connections to aid mental health. Nursing Times, 94 (15), 50-52.

9. Anderson, M.L. (1983). Nursing interventions: What did you do that helped? Perspectives in Psychiatric Care, 21(1), 4-8.

10. Johnson, M., Bulechek, G., Dochterman, J.M., Maas, M., \& Moorhead, S. (2001). Nursing diagnosis, outcomes, and interventions: NANDA, NIC, and NOC linkages. St. Louis, MO: Mosby.

11. Kurlowicz, L.H. (1998). Psychiatric consultation-liaison nursing. In A.W. Burgess (Ed.), Advanced practice psychiatric nursing. Stamford, CT: Appleton \& Lange.

12. Mallory, G.A., Lyons, J.S., \& Scherubel, J.C., \& Reichelt, P.A. (1993). Nursing care hours of patients receiving varying amounts and types of consultation/liaison services. Archives of Psychiatric Nursing, 7, 353-360.
13. Perspectives in Psychiatric Care Vol. 42, No. 1, February, 2006

14. Ragaisis, K.M. (1996). The psychiatric consultation-liaison nurse and medical family therapy. Clinical Nurse Specialist, 10, 50-56.

15. Ozimec, Š. (2000): Zdrastvena njega internističkih bolesnika. Zagreb: VZŠ Kabinet za zdrastvenu njegu

16. Mendaš, Lj., Pavić, J., Županić, M. (2003): Zdrastvena njega u zajednici. Zagreb: VZŠ Katedra za zdrastvenu njegu

17. Sedić, B. (2006): Zdrastvena njega psihijatrijskih bolesnika. Zagreb: Udžbenici i priručnici Zdrastvenog veleučilišsta

18. Čukljek, S. (2006): Proces zdrastvene njege. Zagreb: nastavni tekstovi

19. Fučkar, G. (1995): Proces zdrastvene njege. Zagreb: Udžbenici i priručnici Medicinskog fakulteta Sveučilišta u Zagrebu

20. Fučkar, G. (1996): Uvod u sestrinske dijagnoze. Zagreb: Hrvatska udruga za sestrinsku edukaciju

21. Mandić, N. (1995): Konzultativno - suradna (liaison) psihijatrija. Zagreb: Medicinska naklada

22.Zbornik radova (2001): VII dani psihijatrijske sekcije. Zagreb: Hrvatska udruga medicinskih sestara

23.Zakon o zaštiti osoba s duševnim smetnjama. (1997): Narodne novine, 111.

24.Zakon o psihološkoj djelatnosti. (2003): Narodne novine, 47.

25.Zakon o sestrinstvu. (2003): Narodne novine.

26. Slika preuzeta sa stranice: 1. typesoftherapist. com/images/therapist_3.JPG 


\title{
COMPETENCES OF NURSES IN CONSULTATIVE PSYCHIATRY
}

\author{
Blažinović Ivana, Gurović Andrea, Karlović Dalibor \\ Psychiatric Clinic, CHC Sisters of Mercy, Reference Center for Consultative Psychiatry, Croatian Ministry of \\ Health, Zagreb, Croatia
}

\begin{abstract}
Up to 35 percent of patients, who are treated at the somatic departments, deal not only with somatic disease but also with some forms of psychiatric illnesses or disorders which are most often unrecognized. The modern trend is to include mental and social component to the treatment of somatic diseases in the treatment and care of patients, that is actually holistic and biopsychosocial approach to patients. For this reason, the modern psychiatry has developed a special branch of medicine - consultative psychiatry. In this sense, psychiatric nurses are beginning to emphasize a holistic approach to somatic patients in daily activities. Nurses who work at such a collaborative consultative department of psychiatry must be adequately trained on psychiatric diseases, as well as on physical illnesses, and the etiology of their interconnectedness that will contribute to a better quality of nursing care for patients. Nurses in consultative cooperative psychiatry must also have some experience and relevant education in the work of the psychiatric department with further education through various lectures and seminars in order to respond adequately to identify the etiology of emotional responses to physical illness. The aim of this paper is to demonstrate competences and the importance of nurses in consultative psychiatric work.
\end{abstract}

Key words: competences, nurses, consultative psychiatry

Correspondence:

Dalibor Karlović, MD, $\mathrm{PhD}$

e-mail: dalibor.karlovic@gmail.com 